\title{
TINGKAT KEUNGGULAN BEBERAPA LMS DALAM PEMBELAJARAN DARING PADA MASA PANDEMI COVID-19
}

\section{Agung Tri Adi Wicaksono, Wahyu Andhyka Kusuma}

Universitas Muhammadiyah Malang (UMM) Jawa Timur, Indonesia

Email: dfas69@webmail.umm.ac.id,wahyukusuma@umm.ac.id

\begin{tabular}{ll}
\hline INFO ARTIKEL & ABSTRAK \\
\hline Diterima & Pada masa pandemik COVID-19 semua kegiatan harus dibatasi \\
25 Juli 2021 & dan harus menjaga jarak setiap orang. Termasuk juga kegiatan \\
Direvisi & pembelajaran yang terjadi baik TK, SD, SMP, SMA dan \\
05 Agustus 2021 & Kuliah harus dilakukan secara online / daring. Terdapat \\
Disetujui & berbagai Learning Management System (LMS) yang sangat \\
15 Agustus 2021 & membantu dalam pembelajaran Online, diantaranya seperti \\
\hline Kata Kunci: & ZOOM, Moodle, Google Meet, Google Classroom dan \\
moodle; zoom; & Whatsapp. Artikel ini akan mencari keunggulan dari setiap \\
google meet; google & LMS mana yang lebih efektif. Metode yang digunakan \\
classroom; whatsapp & $\begin{array}{l}\text { menggunakan data-data yang ada di berbagai artikel sebagai } \\
\text { acuan. Hasil dari penelitian ini adalah menentukan LMS mana } \\
\end{array}$ \\
& $\begin{array}{l}\text { yang paling baik digunakan untuk pelajar berserta kelebihan } \\
\text { dan kekurangan nya. }\end{array}$
\end{tabular}

\section{ABSTRACT}

During the COVID-19 pandemic, all activities must be limited and everyone must keep their distance. Including learning activities that occur in kindergarten, elementary, junior high, high school and lectures must be carried out online. There are various Learning Management Systems (LMS) that are very helpful in online learning, such as ZOOM, Moodle, Google Meet, Google Classroom and Whatsapp. This article will Keywords: moodle; explore the advantages of each LMS which is more effective. zoom; google meet; The method used uses data in various articles as a reference. google classroom; The result of this study is to determine which LMS is best used whatsapp for students and their advantages and disadvantages.

\section{Pendahuluan}

Wabah corona virus disease 2019 (COVID-19) telah melanda 215 negara di dunia. Pemerintah telah melarang untuk berkerumun, pembatasan sosial (sosial distancing) dan menjaga jarak fisik (physical distancing) memakai masker dan selalu mencuci tangan. Yang menyebabkan sekitar 45 juta siswa tidak dapat melanjutkan kegiatan belajar mengajar (Hambatan \& Jarak, 2020) Kemendikbud telah melarang

$\begin{array}{ll}\text { How to cite: } & \text { Wicaksono, A. T. A., \& Kusuma, W. A. (2021) Tingkat Keunggulan Beberapa LMS dalam } \\ & \begin{array}{l}\text { Pembelajaran Daring pada Masa Pandemi Covid-19. Jurnal Syntax Admiration 2(8). } \\ \text { https://doi.org/10.46799/jsa.v2i7.264 }\end{array} \\ \text { E-ISSN: } & 2722-5356 \\ \text { Published by: } & \text { Ridwan Institute }\end{array}$


perguruan tinggi melakukan tatap muka dan meminta untuk melakukan kegiatan belajar mengajar dengan metode daring/online. Pembelajaran daring adalah pembelajaran yang menggunakan jaringan internet untuk proses pembelajaran (Sadikin \& Hamidah, 2020). Pada pembelajaran daring banyak masalah yang timbul dalam dunia pendidikan seperti meningkatnya angkat Drop Out (DO), masalah kesiapan pengajar dalam pembelajaran daring, dan kurang nya tatap muka dengan pengajar menyebabkan kurang nya motivasi siswa/mahasiswa untuk melakukan kegiatan belajar (Yustika et al., 2019). Setiap Perguruan Tinggi harus mempunyai media pembelajaran menggunakan teknologi digital yang memudahkan mahasiswa untuk mengakses materi yang ada di perkuliahaan sehingga bisa mengakses dimana saja dan kapan saja. Hal ini sesuai dengan UU RI No 20 Tahun 2003 tentang Sistem Pendidikan Nasional, UU No. 12 tahun 2012 tentang Pendidikan Tinggi dan Peraturan Menteri Pendidikan dan Kebudayaan Nomor 109 Tahun 2013 tentang Penyelenggaraan Pendidikan Jarak Jauh pada Pendidikan Tinggi, UU RI No 20 Tahun 2003 tentang Sistem Pendidikan Nasional dan UU No. 12 tahun 2012 tentang Pendidikan Tinggi dan Peraturan Menteri Pendidikan dan Kebudayaan Nomor 109 Tahun 2013 tentang Penyelenggaraan Pendidikan Jarak Jauh pada Pendidikan Tinggi (Wida, 2020). Pembelajaran juga harus dilakukan sama anak kecil yang dengan menggunakan sistem informasi yang berbasis web atau menggunakan media yang lebih gampang yaitu Whatsapp yang ada untuk memudahkan kegiatan pembelajaran sejak dini (Rakhmawati et al., 2021).

E-Learning merupakan sistem pembelajaran di internet yang dapat menghubungkan antara guru dan murid dalam sebuah kegiatan belajar mengajar online. E-learning tercipta untuk mengatasi keterbatasan antara guru dan murid, terutama dalam hal waktu, ruang, kondisi dan keadaan. Melalui e-learning maka guru dan murid tidak harus berada dalam satu ruang dan waktu bisa melalui media online, proses pendidikan dapat berjalan kapan saja (Meliyani et al., 2019).

E-Learning memiliki kelebihan diantaranya siswa/mahasiswa dapat mengakses kapan pun, pembelajaran serba otomatis. Namun juga ada kekurangannya diantaranya seperti mudah kehilangan fokus bagi siswa/mahasiswa karena tidak diawasi langsung, pembelajaran yang monoton, forum diskusi yang kurang optimal karena tidak tatap muka secara langsung, kurang nya ketrampilan IT dan akses internet yang tidak merata di Indonesia (Agung \& Wibowo, 2020). Ada 3 pembelajaran dalam E-Learning, yang pertama Web Course merupakan media pembelajaran daring menggunakan internet yang tidak ada tatap muka dalam kegiatanya, yang kedua Web Centric Course yaitu menekankan semua menggunakan tatap muka dengan media online namun dengan proses pembelajaran yang lebih kecil, yang ketiga Web Echanced Course yaitu internet hanya untuk mendukung kegiatan pembelajaran tatap muka lebih besar (Astuti \& Febrian, 2019). Dalam penggunaan E-Learning di Sekolah/Universitas dapat menggunakan beberapa platform atau Learning Management System (LMS) yang sudah tersedia dan gratis atau juga bisa membuat LMS sendiri. Pengembangan E-Learning dilakukan sesuai dengan kebutuhan pengguna pada sekolah maupun universitas setelah melakukan pengembangan di harapkan dapat meningkatkan proses belajar mengajar 
yang sudah di kembangkan (Washington et al., 1983). Ada beberapa komponen yang harus di perhatikan dalam penerapan E-Learning yaitu (1) Menyiapkan materi dan capaian pembelajaran; (2) Menyediakan contoh dan praktik untuk memudahkan pembelajaran; (3) Menggunakan teks dan gambar yang menarik; (4) Pembelajaran bisa dilakukan secara langsung; (5) Menyiapkan referensi lain yang berhubungan dengan materi; (6) Membangun wawasan bersama tentang E-Learning agar bisa memakainya dengan optimal (Vinet \& Zhedanov, 2011).

E-Learning memiliki dampak yang dirasakan oleh siswa/mahasiswa dan dosen. Dampak yang dirasakan siswa/mahasiswa diantaranya diharuskan belajar mandiri jika ada pertanyaan atau hambatan maka akan kesulitan untuk bertanya karena tidak tatap muka langsung walaupun sudah di sediakan fitur tanya jawab maka akan merasa tidak enak jika bertanya.Yang kedua adalah sinyal karena setiap daerah memiliki akses internet yang berbeda-beda dan tidak merata di setiap daerahnya yang menyebabkan terhambatnya proses pembelajaran. Jika ada mata kuliah yang mewajibkan untuk melakukan praktik maka akan kesusahan karena tidak ada interaksi tatap muka. Siswa/mahasiswa menerima banyak tugas yang menumpuk karena pada saat ingin mengerjakan mungkin ada kendala kendala seperti internet yang lambat. Dan dengan terjadinya pandemik dan perkuliahan daring ini membuat siswa/mahasiswa minat dalam belajar menurun (Wijaya et al., 2020). Adapun dampak yang diraskan oleh dosen/pengajar jika pada saat melakukan kegiatan pembelajaran siswa/mahasiswa yang mengikuti kegiatan tidak lengkap atau hanya sedikit karena beberapa hambatan. Pada saat pemberian tugas memang memudahkan bagi dosen karena sudah bisa otomatis dalam pengecekan jawaban, jika memberikan tugas juga mudah karena tinggal di upload ke salah satu LMS maka sudah terbagikan langsung ke siswa/mahasiswa. ELearning juga menguntungkan bagi dosen termasuk biaya untuk pulang-pergi ke Sekolah/Universitas. Namun tidak semua dosen/pengajar memahami tentang $E$ Learning dan LMS maka akan terhambatnya proses pembelajaran. (Wijaya et al., 2020) Sudah terdapat penelitian tentang kesiapan dosen/pengajar dalam melaksanakan $E$ Learning karena kesiapan dosen/pengajar sangat berpengaruh terhadap keberhasilan peserta didik, dan dari survei yang diadakan dari 20 dosen/pengajar sebesar $65 \%$ yang sudah siap dalam pembelajaran E-Learning dan sisanya yang 35\% belum siap sepenuhnya untuk mengadakan pembelajaran E-Learning beberapa faktornya diantaranya sinyal, biaya untuk paket internet dan sulitnya untuk memberikan materi jika belum paham tentang E-Learning (Jalal, 2020). Pemahaman tentang IT juga sangat di perlukan baik untuk dosen/pengajar ataupun mahasiswa/siswa, sayangnya yang terjadi di wilayah-wilayah desa tertentu kurangnya literasi tentang computer dan cara menggunakan aplikasi LMS dan melakukan kegiatan E-Learning (Yustika et al., 2019). Tingkat kepuasan pengguna E-Learning dapat di cari dengan dua metode yaitu Metode DeLone dan MeLean, metode tersebut merupakan metode yang paling sering digunakan untuk mengukur kesuksesan sebuah sistem informasi yang diukur dari kualitas sistem, kualitas informasi, kualitas pelayanan,tingkat kepuasan, manfaat bagi pengguna (Larasati \& Andayani, 2019). 
Pada pembelajaran E-Learning siswa/mahasiswa harus memilki motivasi dan semangat dalam pembelajaran karena dalam pandemi ini harus mengikuti alurnya agar kita tidak tertinggal dalam kegiatan pembelajaran. Motivasi yang dimaksud adalah sesuatu yang di dalam diri kita yang dapat menggerakan dan menyebabkan suatu tindakan yang diharapkan (Sujiwo \& A'yun, 2020). Perlu adanya motivasi karena pada saat ini pembelajaran berpusat di dua arah antara dosen/pengajar dan siswa/mahasiswa karena kegiatan pembelajaran sekarang lebih pasif dari pada pembelajaran tatap muka (Daniati et al., 2020). Terdapat komponen-komponen motivasi belajar diantaranya; (1) Attention yaitu munculnya perhatian dari seseorang; (2) Relevance kebutuhan yang di butuhkan oleh siswa/mahasiswa; (3) Confidence yaitu interaksi dengan lingkungan nya; (4) Satisfation yaitu perasaan senang pada saat melakukan kegiatan (Sujiwo \& A'yun, 2020).

Pada artikel ini akan membahas tingkat keunggulan beberapa LMS yang ada seperti ZOOM, Moodle, Google Meet, Google Classroom, Edmodo dan Whatsapp (Agung \& Wibowo, 2020). LMS memiliki beberapa ciri diantaranya manajemen isi pelajaran, manajemen proses pembelajaran, evaluasi dan ujian online, serta chatting dan diskusi. LMS memiliki beberapa kelebihan dan kekurangan masing- masing. Tergantung pelajar atau pengajar memilih media $L M S$ yang mana pada saat mengadakan kegiatan pembelajaran.

\section{Metode Penelitian}

Metode penelitian menggunakan metode descriptive yang digunakan untuk menentukan mana yang labih unggul dari beberapa LMS yang ada dan yang di pakai pada masa pandemi ini. Walaupun sebenarnya dari setiap LMS memiliki kelebihan dan kekurangannya tinggal pilihan dari dosen/pengajar dan siswa/mahasiswa. Menggunakan perbandingan antara berbagai $L M S$ yang ada dari jurnal-jurnal yang telah ada kemudian di bandingkan antara $L M S$ yang ada.

Penelitian menggunakan data yang berupa hasil kuesioner yang di bagi ke beberapa pelajar yang menggunakan sistem pembelajaran daring menggunakan LMS. Dan pertanyaan dari kuesioner tersebut berhubungan dengan tingkat kepuasan pelajar pada saat pembelajaran daring.

\section{Hasil dan Pembahasan}

Pertama adalah Moodle suatu LMS yang dapat memasukan materi, diskusi, tugas dan quiz. Dan guru bisa mengatur waktu atau set-up waktunya namun para siswa/mahasiswa harus masuk kedalam kelas dan di beri akses untuk melihatnya (Vinet \& Zhedanov, 2011). Dengan penggunaan yang benar maka penggunaan nya yang sangat membantu dan siswa/mahasiswa dapat berkomunikasi dengan pengajjar tanpa ada hambatan apapun. Dari penelitian yang sudah ada telah dilakukan angket tingkat kepuasan dari yang sudah/pernah memakai Moodle. Yang mendapatkan data seperti berikut : 
Tabel 1

Hasil Analisis Angket dari Mashasiswa tentang Moodle (Meliyani et al, 2019)

\begin{tabular}{|c|c|c|c|c|c|}
\hline \multirow{2}{*}{ No } & \multirow{2}{*}{ Indikator } & \multicolumn{4}{|c|}{ Persetase \% } \\
\hline & & SS & $\mathbf{S}$ & ST & TS \\
\hline 1 & Penerapan e-learning berbasis moodle menyenangkan & 9,7 & 65,3 & 18 & 7 \\
\hline 2 & $\begin{array}{l}\text { Mudah mengakses materi di e-learning berbasis } \\
\text { moodle }\end{array}$ & 10 & 75 & 10 & 5 \\
\hline 3 & $\begin{array}{l}\text { Mudah Mengirimkan Tugas di e-learning berbasis } \\
\text { moodle }\end{array}$ & 8 & 75,3 & 10 & 6,7 \\
\hline 4 & $\begin{array}{l}\text { Dapat melihat nilai tugas dan quis di e-learning } \\
\text { berbasis moodle }\end{array}$ & 10,7 & 76 & 8 & 5,3 \\
\hline 5 & $\begin{array}{l}\text { Dapat belajar dari sumber lain di e-learning berbasis } \\
\text { moodle }\end{array}$ & 4,4 & 74,3 & 20,3 & 1 \\
\hline 6 & $\begin{array}{l}\text { Dapat berinteraksi dengan teman sekelas melalui } \\
\text { diskusi di e-learning berbasis moodle }\end{array}$ & 9,7 & 65,3 & 18 & 7 \\
\hline 7 & $\begin{array}{l}\text { Dapat berinteraksi dengan dosen melalui diskusi di } e \text { - } \\
\text { learning berbasis moodle }\end{array}$ & 10 & 72,5 & 17,5 & 0 \\
\hline 8 & u mengakses e-learning berbasis moodle dengan & 6,9 & 72,1 & 18 & 3 \\
\hline 9 & $\begin{array}{l}\text { Dapat mengakses e-learning berbasis moodle kapan } \\
\text { saja }\end{array}$ & 8,1 & 85 & 6,9 & 0 \\
\hline 10 & $\begin{array}{l}\text { Membutuhkan paket data dalam mengakses } \text { e-learning } \\
\text { berbasis moodle }\end{array}$ & 70 & 26 & 4 & 0 \\
\hline 11 & Biaya paket data mahal harganya & 55 & 43 & 2 & 0 \\
\hline 12 & Saya kekurangan biaya membeli paket data & 57 & 40 & 3 & 0 \\
\hline 13 & Saya belum mempunyai laptop/komputer & 30 & 65 & 5 & 0 \\
\hline 14 & Saya tidak bisa mengakses $e$-learning & 10 & 20 & 70 & 0 \\
\hline 15 & a belum ada jaringan internet & 9 & 71,3 & 18 & 1,7 \\
\hline 16 & Jaring & 11,9 & 65,3 & 16,8 & 6 \\
\hline 17 & $\begin{array}{l}\text { Saya harus mencari lokasi yang ada jaringan internet } \\
\text { untuk mengakses } e \text {-learning berbasis moodle }\end{array}$ & 6 & 68,3 & 18,7 & 7 \\
\hline 18 & $\begin{array}{l}\text { Mengakses e-learning berbasis moodle membuat saya } \\
\text { stress }\end{array}$ & 20 & 30 & 46 & 4 \\
\hline 19 & $\begin{array}{l}\text { Mengakses e-learning berbasis moodle, memberikan } \\
\text { wawasan tentang metode pembelajaran }\end{array}$ & 10 & 75 & 15 & 0 \\
\hline 20 & $\begin{array}{l}\text { Saya sebelumnya pernah mengakses e-learning } \\
\text { berbasis moodle }\end{array}$ & 30 & 65,3 & 3,7 & 1 \\
\hline & & 19,3 & 61,5 & 16,4 & 2,7 \\
\hline
\end{tabular}

Kemudian dari data tersebut sebanyak 19,3\% Mahasiswa menjawab SS (Sangat Setuju), 61,5\% menjawab S (Setuju), 16,4\% menjawab TS (Tidak Setuju), 2,7\% menjawab STS (Sangat Tidak Setuju). Dari penjelasan mahasiswa yang menjawab tidak setuju dan sangat tidak setuju dikarenakan kendala device baik handphone maupun laptop atau koneksi yang kurang memadai. (Meliyani et al., 2019). Pembelajaran dengan moodle juga bisa di tingkatkan kefeektifitasanya dengan metode blanded learning karena metode ini bisa menambahkan keinginan untuk belajar.

Berikutnya ada LMS Google Classroom atau bisa di sebut denngan Virtual Classroom, Google Classroom adalah suatu LMS yang disediakan oleh Google yang di 
dalamnya ada beberapa fitur yang dapat memberi tugas, memberi nilai, membagikan materi dan percakapan online dengan pengajar. Keunggulanya dapat menyimpan data dari Google drive serta langsung tersambung dengan Email yaitu Gmail (Alfina, 2020). Google classroom juga dapat meningkatkan motivasi dalam pembelajaran dan hasil dari mahasiswa (Daniati et al., 2020). Berdasarkan hasil pembagian angket tentang Google classroom telah mendapatkan grafik sebagai berikut:

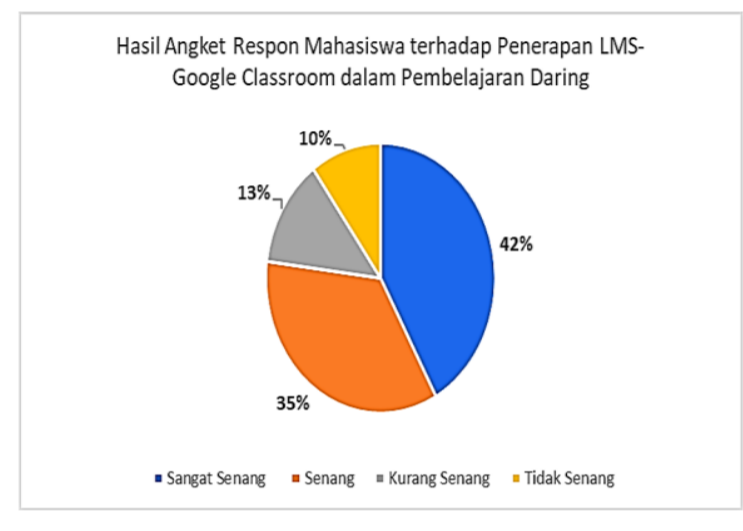

\section{Gambar 1 \\ Hasil Perhitungan Angket Mahasiswa}

(Alfina, 2020)

Berdasarkan data yang didapat sebanyak 77\% mahasiswa SS (Sangat Senang) dan menyukai pembelajaran menggunakan LMS Google Classroom dan sisanya merasa KS (Kurang Senang) dan lebih baik memakai LMS lain.

Pembelajaran juga harus melakukan tatap muka agar memudahkan dalam menyampaikan materi dari dosen/pengajar ke siswa/mahasiswa. Salah satu $L M S$ yang dapat digunakan untuk tatap muka yaitu Zoom Meet walaupun bukan sepenuhnya digunakan untuk pembelajaran namun sering digunakan untuk proses mengajar. Zoom Meet didirikan oleh Erik Yuan yang diresmikan tahun 2011 yang sampai sekarang masih di gunakan dan malah sangat berguna (Haqien \& Rahman, 2020). Terdapat tingkat efektifitas dari Zoom meet dari beberapa responden mahasiswa berikut tabelnya:

\section{Tabel 2}

Hasil Tingkat Efektif atau Tidak Zoom meet (Haqien \& Rahman, 2020)

\begin{tabular}{cc}
\hline Pendapat Mahasiswa & Total Presentase \\
\hline Efektif & $70 \%$ \\
\hline Tidak Efektif & $30 \%$ \\
\hline
\end{tabular}

Namun Zoom meet dirasa kurang efektif karena sering terjadi masalah atau ada problem seperti jaringan internet apalagi bagi siswa atau mahasiswa yang tidak memilki wifi akan kesusaan dan tidak stabil. Tadi memiliki kelebihan bisa di bilang penggunaan nya yang praktis dan efisien bagi masiswa karena lebih mudah saat digunakan untuk berkomuniasi dengan pengajar lewat zoom dari pada lewat chat.

Kemudian dalam proses pembelajaran E-Learning tentunya harus ada media komunikasi atau chat untuk memperlancar proses pengajaran dan penyampaian materi. 
Whatssapp merupakan suatu media sosial yang dapat digunakan untuk mempermudah proses pembelajaraan karena tersedianya internet di mana-mana. Karena Whatssap merupakan suatu media sosial yang paling gampang di pahami dan paling gampang untuk digunakan. Sampai aplikasi whatssapp menjadi aplikasi yang paling di minati kedua (Nabilla \& Kartika, 2020). Proses pembelajaran biasanya melalui fitur whatssap grup, para pengajar membuat dan menambahkan ketua kelas/ketua tingkat untuk menambahkan semua siswa/mahasiswa untuk masuk ke dalam grup tersebut.

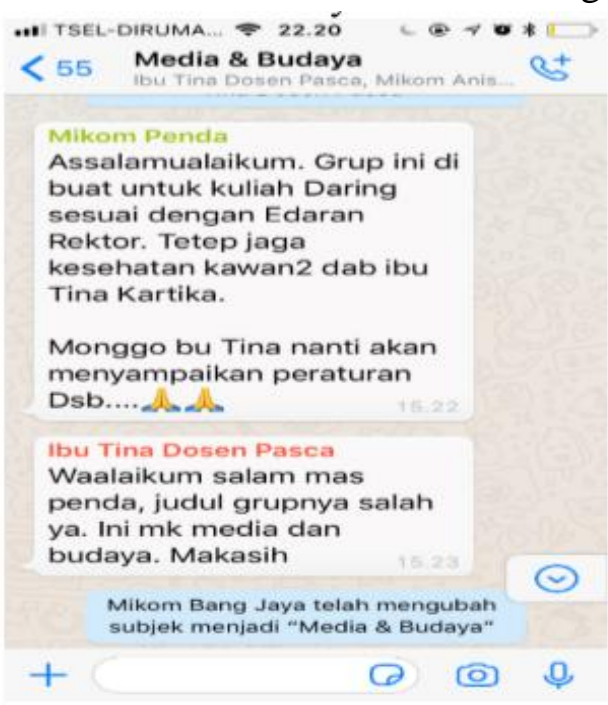

\section{Gambar 2}

Grup Whatsapp Sebagai Media Pembelajaran

(Nabilla \& Kartika, 2020)

Pada Whatsapp juga bisa digunakan untuk membagi soal pemberian materi dan absensi yang berguna dan sangat simple seperti gambar di bawah ini :

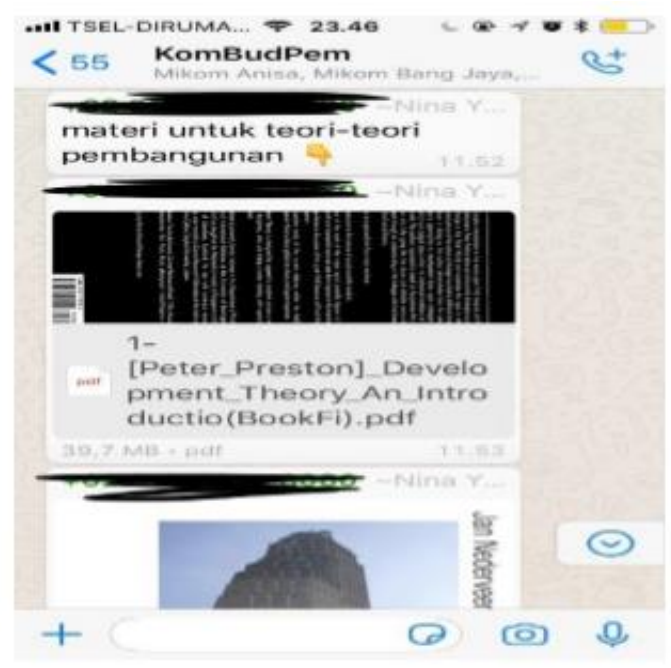

Gambar 3

Grup Whatsapp dapat Sebagai pemberian materi

(Nabilla \& Kartika, 2020) 


\section{Kesimpulan}

Kesimpulan yang di dapat dari hasil penelitian diatas bahwa setiap pada pandemi COVID-19 ini harus menjalankan kegiatan pembelajaran daring/E-Learning. Dan pada saat ini $L M S$ menjadi media yang paling membantu dalam kegiatan belajar mengajar karena dapat memudahkan beban dosen maupun beban mahasiswa karena tidak bisa melakukan proses belajar mengajar secara tatap muka.

Setiap LMS memiliki kelebihan masing masing seperti Moodle memiliki kelebihan seperti fiturnya lengkap, mudah di pahami, tidak memakai ruang yang banyak. Sesuai dengan hasil survey bahwa sekitar $80 \%$ lebih menganggap bahwa moodle itu efektif.

Begitu juga dengan Google classroom yang memiliki kelebihan seperti mudah di pahami, langsung menyambung dengan Email, dan menyambung ke Google Drive. Dari data yang didapat dari $77 \%$ dari responden sangat senang dengan adanya Google clasroom.

Zoom Meet sangat membantu dalam perkuliahan apalagi untuk tatap muka walaupun ada kekurangannnya seperti jika jaringan tidak memadai maka akan putus atau keluar dari ruang meet dan borosnya paket internet jika memakai Zoom Meet. Dari data responden sebanyak $70 \%$ merasa bahwa penggunaan zoom meet itu efektif.

Media chat yang paling sering digunakan sekarang adalah Whatsapp. Whatsapp juga membantu dalam proses perkuliahan online karena banyak digunakan untuk grup kelas jika ada pembagian tugas ataupun tanya jawab antara pengajar dan pelajar.

Semua LMS bagus dan memiliki kelebihan dan kekurangannya masing-masing tinggal kita menyesuaikan dengan kebutuhan kita. Jadi kita memilih apa yang kita butuhkan dan kita akan menggunakan $L M S$ tersebut untuk mempermudah proses pembelajaran.

Jika di ambil dari data yang di dapat kan bahwa dapat di sumpulkan dari beberapa $L M S$ yang dijelaskan Moodle menjadi yang paling lengkap dalam fitur untuk melakukan proses pembelajaran daring. 


\section{BIBLIOGRAFI}

Agung, F., \& Wibowo, N. (2020). Media Pembelajaran E-Learning Saat PJJ ( Pendidikan Jarak Jauh ). May, 8-11. Google Scholar

Alfina, O. (2020). Penerapan Lms-Google Classroom Dalam Pembelajaran Daring Selama Pandemi Covid-19. Majalah Ilmiah METHODA, 10 (1), 38-46. https://doi.org/10.46880/methoda.v10i1.537. Google Scholar

Astuti, P., \& Febrian, F. (2019). Blended Learning: Studi Efektivitas Pengembangan Konten E-Learning Di Perguruan Tinggi. Jurnal Tatsqif, 17 (1), 104-119. https://doi.org/10.20414/jtq.v17i1.972. Google Scholar

Daniati, D., Ismanto, B., \& Luhsasi, D. I. (2020). Upaya Peningkatan Motivasi dan Hasil Belajar Mahasiswa dengan Penerapan Model Pembelajaran E-Learning Berbasis Google Classroom pada Masa Pandemi Covid-19. Jurnal Kependidikan: Jurnal Hasil Penelitian Dan Kajian Kepustakaan Di Bidang Pendidikan, Pengajaran Dan Pembelajaran, 6 (3), 601. https://doi.org/10.33394/jk.v6i3.2642. Google Scholar

Hambatan, M., \& Jarak, P. (2020). Indonesia di Masa Krisis Pandemi Covid-19. Ringkasan Kebijakan, 19 (2), 1-9. Google Scholar

Haqien, D., \& Rahman, A. A. (2020). Pemanfaatan Zoom Meeting untuk Proses Pembelajaran pada Masa Pandemi Covid-19. SAP (Susunan Artikel Pendidikan), 5 (1). https://doi.org/10.30998/sap.v5i1.6511. Google Scholar

Jalal, M. (2020). Kesiapan Guru Menghadapi Pembelajaran Jarak Jauh Di Masa Covid19. SMART KIDS: Jurnal Pendidikan Islam Anak Usia Dini, 2 (1), 35-40. Google Scholar

Larasati, N. A., \& Andayani, S. (2019). Pengaruh Penggunaan Learning Management System (LMS) Terhadap Tingkat Kepuasan Mahasiswa Menggunakan Metode DeLone and McLean. Jurnal Teknik Informatika UNIKA Santo Thomas, 4 (1), 1320. Google Scholar

Meliyani, M., Supriyanto, S., \& Rahmattullah, M. (2019). Pengaruh Pemanfaatan Simari sebagai Implementasi Pembelajaran Berbasis E-Learning terhadap Hasil Belajar Mahasiswa Prodi Pendidikan Ekonomi. Jurnal Pendidikan Ilmu Sosial, 29 (1), 1-8. Google Scholar

Nabilla, R., \& Kartika, T. (2020). WhatsApp Grup Sebagai Media Komunikasi Kuliah Online. Jurnal Interaksi : Jurnal Ilmu Komunikasi, 4 (2), 193-202. https://doi.org/10.30596/interaksi.v4i2.4595. Google Scholar 
Rakhmawati, N. I. S., Mardliyah, S., Fitri, R., Darni, D., \& Laksono, K. (2021). Pengembangan Learning Management System (LMS) di Era Pandemi Covid-19 pada Pendidikan Anak Usia Dini. Jurnal Obsesi : Jurnal Pendidikan Anak Usia Dini, 6 (1), 107-118. https://doi.org/10.31004/obsesi.v6i1.991. Google Scholar

Sadikin, A., \& Hamidah, A. (2020). Pembelajaran Daring di Tengah Wabah Covid-19. Biodik, 6 (2), 109-119. https://doi.org/10.22437/bio.v6i2.9759. Google Scholar

Sujiwo, D. A. C., \& A'yun, Q. (2020). Pengaruh Pemanfaatan E-learning Terhadap Motivasi Belajar Mahasiswa. JUSTINDO (Jurnal Sistem Dan Teknologi Informasi Indonesia), 5 (2), 53-59. Google Scholar

Vinet, L., \& Zhedanov, A. (2011). A “missing" family of classical orthogonal polynomials. Journal of Physics A: Mathematical and Theoretical, 44 (8), 16891699. https://doi.org/10.1088/1751-8113/44/8/085201. Google Scholar

Washington, A. C., Rosser, P. L., \& Cox, E. P. (1983). Contraceptive practices of teenage mothers. Journal of the National Medical Association, 75 (11), 10591063. Google Scholar

Wida, S. (2020). Respon Mahasiswa Pada Mata Kuliah Daring. Child Education Journal, 2 (1), 48-52. https://doi.org/10.33086/cej.v2i1.1506. Google Scholar

Wijaya, R., Lukman, M., \& Yadewani, D. (2020). Dampak Pandemi Covid-19 Terhadap Pemanfaatan E-Learning. Dimensi, 9 (2), 307-322. Google Scholar

Yustika, G. P., Subagyo, A., \& Iswati, S. (2019). Masalah Yang Dihadapi Dunia Pendidikan Dengan Tutorial Online: Sebuah Short Review. Tadbir: Jurnal Studi Manajemen Pendidikan, 3 (2), 187. https://doi.org/10.29240/jsmp.v3i2.1178. Google Scholar

\section{Copyright holder:}

Agung Tri Adi Wicaksono, Wahyu Andhyka Kusuma (2021)

First publication right:

Jurnal Syntax Admiration

This article is licensed under: 